\title{
RESPONSE AND YIELD STABILITY OF CANOLA (Brassica napus L.) GENOTYPES TO MULTI-ENVIRONMENTS USING GGE BIPLOT ANALYSIS
}

\author{
Mehmet Sincik ${ }^{1}$, Abdurrahim Tanju Goksoy ${ }^{1}$, Emre Senyigit ${ }^{2}$, Yahya Ulusoy ${ }^{3}$, Mustafa Acar $^{4}$, \\ Sahin Gizlenci ${ }^{4}$, Gulhan Atagun ${ }^{4}$ and Sami Suzer ${ }^{5}$
}

\begin{abstract}
The GxE interaction (GEI) provides essential information for selecting and recommending cultivars in multi-environment trials. This study aimed to evaluate genotype $(\mathrm{G})$ and environment (E) main effects and GxE interaction of 15 canola genotypes (10 canola lines and 5 check varieties) over 8 environments and to examine the existence of different mega environments. Canola yield performances were evaluated during 2015/16 and 2016/17 production season in three different locations (Southern Marmara, Thrace side of Marmara, and Black Sea regions) of Turkey. The trial in each location was arranged in a randomized complete block design with four replications. The seed yield data were analyzed using GGE biplot and the yield components data were analyzed using ANOVA. The agronomical traits revealed that environments, genotypes, and GEI were significant at $1 \%$ probability for all of the characters. The variance analysis exhibited that genotypes, environments, and GEI explained 21.6, 21.7, and $25.7 \%$ of the total sum of squares for seed yield, respectively. The GGE biplot analysis showed that the first and second principal components explained 57.3 and $18.3 \%$ of the total variation in the data matrix, respectively. GGE biplot analysis showed that the polygon view of a biplot is an excellent way to visualize the interactions between genotypes and environments. Additional keywords: Genotype x environment interaction, multi-environment trials, seed yield, yield components
\end{abstract}

\section{RESUMEN}

Estabilidad de rendimiento de genotipos de canola (Brassica napus L.) a multi-ambientes usando el análisis biplot GGE La interacción genotipo $\mathrm{x}$ ambiente (IGA) proporciona información esencial para seleccionar y recomendar cultivares en ensayos multi-ambiente. Este estudio tuvo como objetivo evaluar los efectos principales del genotipo y el ambiente, y la IGA, de 15 genotipos de canola en ocho ambientes y examinar la existencia de diferentes mega-ambientes. El rendimiento de la canola se evaluó durante la temporada 2015/16 y 2016/17 en tres lugares distintos (Mármara meridional, el lado Thrace de Mármara, y regiones del Mar Negro) en Turquía. El ensayo en cada ubicación se organizó en un diseño de bloques completos al azar con cuatro repeticiones. Los datos de rendimiento de semillas se analizaron usando GGE biplot y los datos de componentes de rendimiento mediante ANOVA. El análisis de los rasgos agronómicos reveló que los ambientes, genotipos e interacciones genotipo $\times$ ambiente $(\mathrm{IGA})$ fueron significativos al $1 \%$ de probabilidad para todos los caracteres. El análisis de varianza mostró que los genotipos, ambientes y el IGA explicaron $21,6 \%, 21,7 \%$ y $25,7 \%$ de la suma total de cuadrados para el rendimiento de semillas, respectivamente. El análisis biplot GGE mostró que el primer y el segundo componente principal explicaron el 57,3 y $18,3 \%$ de la variación total en la matriz de datos, respectivamente. El análisis de biplot de GGE mostró que la vista poligonal de un biplot es una forma excelente de visualizar las interacciones entre genotipos y ambientes.

Palabras-clave adicionales: Componentes del rendimiento, ensayos multiambiente, IGA, rendimiento de semilla

\section{INTRODUCTION}

The development of high-yielding and stable varieties is the main purpose of most breeding programs. The genotype $\mathrm{x}$ environment interaction is particularly important in the improvement and

Received: May 25, 2020

Accepted: January 13, 2021

${ }^{1}$ Department of Field Crops, Faculty of Agriculture, Uludag University, Bursa, Turkey. e-mail: sincik@uludag.edu.tr (corresponding author); agoksoy@uludag.edu.tr

${ }^{2}$ Vocational School of Mustafa Kemalpasa, Uludag University, Bursa, Turkey. esenyigit@uludag.edu.tr

${ }^{3}$ Vocational School of Technical Science, Uludag University, Bursa, Turkey. e-mail: yahyau@ uludag.edu.tr

4 Black Sea Agricultural Research Institude, Samsun, Turkey. e-mail: mustafacar_tr@yahoo.com; sahin_gizlenci@yahoo.com; gulhan53@gmail.com

${ }^{5}$ Trakya Agricultural Research Institude, Edirne, Turkey. suzersami@yahoo.com 
evaluation of plant cultivars (Miah et al., 2015). Phenotypes are a mixture of genotype $(\mathrm{G})$ and environment (E) components and their interactions (GEI) complicate the process of selecting genotypes with superior performance (Shojaei et al., 2011). Although the measured yield is a combined result of the effects of $G, E$, and GEI, only $G$ and GEI are relevant to cultivar evaluation and mega-environment identification (Yan et al., 2000; Otoo and Asiedu, 2006). Experimental trials are usually set up in various environments to evaluate the yield stability of different plant species under distinct environmental conditions (Yan et al., 2000). It is important to evaluate new genotypes at different locations for several years to determine the stability of cultivar candidates. A genotype grown in different environments will frequently show significant fluctuations in yield performance (Rahnejat and Farshadfar, 2015).

The GGE biplot methodology of analysing multi-environment trial (MET) data has been well documented (Yan and Tinker, 2006). The biplot technique was used to display the GGE of METs data, referred to as a GGE biplot (Yan et al., 2000). A biplot is a scatter plot that approximates and graphically displays a two-way table by both its row and column factors in a way that relationships among row factors, relationships among column factors, and interactions between row and column factors can be simultaneously visualized (Otoo and Asiedu, 2006). Besides, a GGE biplot can reveal the "which-won-where" pattern of a MET data, which is important for mega-environment identification and for cultivar recommendations specific to each megaenvironment (Yan and Tinker, 2005). In the GGE biplot analysis, the purpose of the testenvironment evaluation is to identify the environments that effectively identify superior genotypes for a mega-environment. The ideal environment is located in the first concentric circle in the environment-focused GGE biplot, and the environments that are close to the ideal environment are defined as the desired environments. The multi-environment analysis, especially GGE biplot, has been used by many researchers in recent years for explaining GEI and quantifying the adaptability and stability of tested canola genotypes (Shojaei et al., 2011; Nowosad et al., 2016; Zhang et al., 2017).
The aims of the present study were: (1) to evaluate genotype $(\mathrm{G})$ and environment $(\mathrm{E})$ main effects and GEI of 15 canola genotypes over 8 environments; (2) to examine the existence of different mega environments by applying the GGE biplot technique; and (3) to determine discriminating ability and representativeness of the environments with this method.

\section{MATERIALS AND METHODS}

The field trials were performed in the production seasons 2015/2016 and 2016/2017 in three different locations (Southern Marmara, Thrace side of Marmara, and Black Sea regions) of Turkey. Fifteen canola genotypes consisting of 10 advanced canola lines and five standard varieties were analyzed by a randomized complete block design with 4 replications. The pedigree of these genotypes and their breeding organizations or variety owner organizations are presented in Table 1.

Table 1. Code, pedigree and breeding organization or variety owner of genotypes

\begin{tabular}{|c|c|c|c|}
\hline Code & Name & Pedigree & $\begin{array}{c}\text { Breeding } \\
\text { organization/ } \\
\text { variety owner }\end{array}$ \\
\hline & \multicolumn{3}{|c|}{ Lines } \\
\hline G1 & SC-04 & Samurai x Chang & Uludag University \\
\hline G2 & BC-12 & Bristol x Chang & Uludag University \\
\hline G3 & QS-18 & Quinta x Samurai & Uludag University \\
\hline G4 & BS-07 & Bristol x Samurai & Uludag University \\
\hline G5 & QB-12 & Quinta x Bristol & Uludag University \\
\hline G6 & CB-16 & Chang x Bristol & Uludag University \\
\hline G7 & QC-25 & Quinta x Chang & Uludag University \\
\hline G8 & SQ-09 & Samurai x Quinta & Uludag University \\
\hline G9 & CQ-05 & Chang x Quinta & Uludag University \\
\hline G10 & SB-28 & Samurai x Bristol & Uludag University \\
\hline \multicolumn{4}{|c|}{ Standards } \\
\hline \multicolumn{3}{|c|}{ G11 Süzer } & $\begin{array}{l}\text { Trakya Agric. } \\
\text { Res. Instit. }\end{array}$ \\
\hline \multicolumn{3}{|c|}{ G12 Orkan } & Agromar Seed Co. \\
\hline \multicolumn{3}{|c|}{ G13 NK Caravel } & Syngenta Seed Co. \\
\hline \multirow{3}{*}{$\begin{array}{l}\text { G14 } \\
\text { G15 }\end{array}$} & calibur & & Monsanto Seed Co. \\
\hline & & & United Genetics \\
\hline & & & Seed Co. \\
\hline
\end{tabular}

In the present study, the growing seasons, environments (E), soil properties, amount of rainfall, and mean temperature during the growing period are also given in Table 2. As seen from this table, the climate characteristics varied according 
to the environments. The sowings were done by using a plot drill in the plots of $10 \mathrm{~m}$ in length consisting of 8 rows in each plot, with a $17.5 \mathrm{~cm}$ row spacing and contains approximately 85 plants $\cdot \mathrm{m}^{-2}$. Sowings of the trials were generally completed from the second half of September until October 10. The $400 \mathrm{~kg} \cdot \mathrm{ha}^{-1}$ 15-15-15 compose fertilizer was applied at the sowing time in the experiments. At the beginning of spring, nitrogen in the form of urea $(46 \% \mathrm{~N})$ in the $100 \mathrm{~kg}$ $\mathrm{ha}^{-1}$ of active substance was added to the plots. Weed control was done by herbicide. Disease and pest control were performed at the required locations.

Days to first flowering, days to last flowering, days to physiological maturity, plant height, capsules per plant, seed per capsule, thousand seed weight, seed yield, crude oil percent, and crude oil yield data were analyzed separately for each environment and combined over environments using ANOVA (Table 3), and mean separation by LSD test. The seed yield data were analyzed using the GGE biplot technique. GGE analysis was used to determine the effects of GEI on yields. The results were visualized in biplot graphs (Yan et al., 2000).

Table 2. Data on the experiment, soil properties and climate for environments where the experiments were conducted

\begin{tabular}{ccccccc}
\hline Code & $\begin{array}{c}\text { Growing } \\
\text { seasons }\end{array}$ & Environments & Soilproperties & $\begin{array}{c}\text { Mean temperatures at } \\
\text { the growing season }\left({ }^{\circ} \mathrm{C}\right)\end{array}$ & $\begin{array}{c}\text { Rainfall } \\
(\mathrm{mm} \cdot \text { year })\end{array}$ & $\begin{array}{c}\text { Mean yield } \\
\left(\mathrm{t} \cdot \mathrm{ha} \mathrm{a}^{-1}\right)\end{array}$ \\
\hline E1 & $2015-16$ & Bursa & $\mathrm{pH}=7.2$, clay & 14.2 & 611.2 & 4.18 \\
E6 & $2017-18$ & Bursa & $\mathrm{pH}=7.2$, clay & 14.6 & 727.7 & 3.97 \\
E2 & $2015-16$ & Edirne & $\mathrm{pH}=6.70$, clay-loam & 13.8 & 577.3 & 4.17 \\
E4 & $2016-17$ & Edirne & $\mathrm{pH}=6.70$, clay-loam & 11.6 & 434.7 & 4.08 \\
E7 & $2017-18$ & Edirne & $\mathrm{pH}=6.70$, clay-loam & 13.4 & 775.9 & 3.60 \\
E3 & $2015-16$ & Samsun & $\mathrm{pH}=7.45$, clay & 14.0 & 1008.8 & 3.97 \\
E5 & $2016-17$ & Samsun & $\mathrm{pH}=7.45$, clay & 11.7 & 747.6 & 3.41 \\
E8 & $2017-18$ & Samsun & $\mathrm{pH}=7.45$, clay & 14.6 & 585.0 & 3.36 \\
\hline
\end{tabular}

Table 3. Mean squares from ANOVA for seed yield and yield components observed from trials conducted with 15 canola genotypes in 8 environments

\begin{tabular}{lcccccc}
\hline \multicolumn{1}{c}{ Characters } & Environment (E) & $\begin{array}{c}\text { Repl. [Envi.] } \\
\text { \&Random }\end{array}$ & $\begin{array}{c}\text { Genotype } \\
(\mathrm{G})\end{array}$ & G x E & Error & CV (\%) \\
\hline DFF & \multicolumn{7}{c}{ Mean squares } \\
DLF & $8289.3^{* *}$ & $2.7^{* *}$ & $394.1^{* *}$ & $76.3^{* *}$ & 265.7 & 0.53 \\
DPM & $6447.8^{* *}$ & 14.1 & $256.1^{* *}$ & $96.7^{* *}$ & 4415.3 & 1.96 \\
PH & $17957.0^{* *}$ & $2.35^{* *}$ & $371.4^{* *}$ & $207.2^{* * *}$ & 0.72 & 0.32 \\
CPP & $18975.8^{* *}$ & 70.7 & $1170.6^{* *}$ & $394.6^{* *}$ & 21002.9 & 5.15 \\
SPC & $89823.4^{* *}$ & $1839.9^{* *}$ & $8177.1^{* *}$ & $2730.5^{* *}$ & 133.4 & 6.86 \\
TSW & $706.6^{* *}$ & 3.42 & $20.3^{* *}$ & $20.7^{* *}$ & 2.61 & 6.31 \\
SY & $9.04^{* *}$ & $0.13^{* *}$ & $0.72^{* *}$ & $0.11^{* *}$ & 0.05 & 4.96 \\
COP & $62623.8^{* *}$ & $11528.5^{* *}$ & $31230.2^{* *}$ & $5310.0^{* *}$ & 1036.8 & 8.27 \\
COY & $1420.9^{* *}$ & 0.64 & $46.0^{* *}$ & $10.7^{* *}$ & 0.46 & 1.55 \\
\% of Total SS for SY & $21862.0^{* *}$ & $2817.2^{* *}$ & $8616.0^{* *}$ & $1083.0^{* *}$ & 200.4 & 8.43 \\
\hline DFF & 21.7 & 13.7 & 21.6 & 25.7 & 17.2 & \\
\hline
\end{tabular}

DFF: days to first flowering; DLF: days to last flowering; DPM: days to physiological maturity; PH: plant height (cm); CPP: capsules per plant; SPC: seed per capsule; SY: seed yield $\left(\mathrm{kg}^{-} \mathrm{ha}^{-1}\right) \mathrm{TSW}$ : thousand seed weight (g); COP: crude oil percent; COY: crude oil yield $\left(\mathrm{kg}^{\mathrm{h}} \mathrm{ha}^{-1}\right)$; SS: sum of squares

The GGE model was as the following: $\mathrm{Y}_{i j}-\mathrm{y}_{j}=$ $\mathrm{y}_{1} \varepsilon_{i 1} \rho_{j 1}+\mathrm{y}_{2} \varepsilon_{i 2} \rho_{j 2}+\varepsilon_{i j}$ where $\mathrm{y}_{i j}$ refers to the mean yield of the population of $i$ order in the environment of $\mathrm{j}$ order; $\mathrm{y}_{\mathrm{j}}$ is the overall mean of genotypes in the $\mathrm{j}$ environment; $\mathrm{y}_{1} \varepsilon_{\mathrm{i} 1} \rho_{\mathrm{j} 1}$ is the first principal component (PC1); $\mathrm{y}_{2} \varepsilon_{\mathrm{i} 2} \rho_{\mathrm{j} 2}$ is the second principal component $(\mathrm{PC} 2) ; \mathrm{y}_{1}$ and $\mathrm{y}_{2}$ are the eigenvalues associated with IPCA1 and IPCA2, respectively; $\varepsilon_{1}$ and $\varepsilon_{2}$ are the values of $\mathrm{PC} 1$ and PC2, respectively, of the i genotype; $\rho_{\mathrm{j} 1}$ and $\rho_{\mathrm{j} 2}$ are the values of PC1 and PC2, respectively, for the $j$ environment; and $\varepsilon i j$ is the error associated with 
the $\mathrm{i}$-th genotype and $\mathrm{j}$-th environment (Yan et al. 2000). PC1 values are placed in the horizontal plane $(\mathrm{X})$ of the GGE biplot graphical plane by expressing the mean of the genotypes examined, whereas PC2 values are the stability state of the studied parameter and are in the vertical plane (Y) of the graph plane.

Yield performance and stability of genotypes were evaluated by an average environment coordination (AEC) method (Yan, 2001; Yan, 2002; Yan and Hunt, 2002). In this method, an average environment is defined by the average PC1 and PC2 scores of all environments, represented by a small circle (Figure 2). A line is then drawn to pass through this average environment and the biplot origin; this line is called the average environment axis and serves as the abscissa of the AEC. The ordinate of the AEC is the line that passes through the origin and is perpendicular to the AEC abscissa (Rahnejat and Farshadfar, 2015). Statistical analyses for GGE biplot were done using GenStat 12th edition statistical software (Yan and Tinker, 2006).

\section{RESULTS AND DISCUSSION}

Environments, genotypes, and GEI effects were found to be statistically significant $(P \leq 0.01)$ for all observed characteristics. The analysis of variance for seed yield revealed that environments, genotypes, and GEI accounted for 21.7, 21.6, and $25.7 \%$ of the total variation, respectively. This result indicated that environments, genotypes, and GEI were important in governing the expression of this character. A highly significant GEI for seed yield indicates the necessity for further stability análisis. In a similar study, it was detected that the differences between environments and genotypes explained 69.8 and $13.7 \%$ of the total yield variation, respectively while the effects of $\mathrm{GxE}$ interaction explained $8.12 \%$ (Nowosad et al., 2016). The coefficient of variation (CV) for all observed characters was low level (0.32\%-9.23\%), indicating experimental precision.

The differences among genotypes were determined in terms of yield and some yield components (Table 4). Average values of canola genotypes overall environments ranged from 159.3 to 171.8 days to first flowering; 179.1 to 188.3 days to last flowering; 264.0 to 274.8 days to physiological maturity; 140.0 to $161.6 \mathrm{~cm}$ for plant height; 146.8 to 195.1 capsules per plant; 24.4 to 27.6 seeds per capsule; 4.13 to $4.58 \mathrm{~g}$ for thousand seed weight; 41.4 to $45.5 \%$ for crude oil and 1448.2 to $2073.4 \mathrm{~kg} \cdot \mathrm{ha}^{-1}$ for crude oil yield. Genotypes, G14 (Excalibur), G13 (NK Caravel), G15 (Elvis), and G2 (BC-28) had the highest mean seed yield overall environments, with a mean yield of 4579.9, 4291.0, 4195.0, and 4126.1 $\mathrm{kg} \cdot \mathrm{ha}^{-1}$, respectively. Those genotypes, except G15, also gave the best results in terms of crude oil yield over the environments (Table 4). Our findings regarding the average of agronomic characters were in agreement with the results of Moghaddam and Pourdad (2011).

The average seed yield of environments over genotypes ranged from $3364.7 \mathrm{~kg} \cdot \mathrm{ha}^{-1}$ for environment E8 to $4182.3 \mathrm{~kg} \cdot \mathrm{ha}^{-1}$ for E1; and seed yield of genotypes over environment ranged from $3515.7 \mathrm{~kg} \cdot \mathrm{ha}^{-1}$ for genotype G4 to $4579.9 \mathrm{~kg} \cdot \mathrm{ha}^{-1}$ for G14 (Table 5). On the other hand, seed yield of genotypes across environments ranged from 2616.3 $\mathrm{kg} \cdot \mathrm{ha}^{-1}$ for G11 (Süzer) at environment E5 to $5304.2 \mathrm{~kg} \cdot \mathrm{ha}^{-1}$ for G15 (ELVIS) at environment E3. The results revealed that newly developed breeding lines yielded lower yields compared to check varieties. The significant GEI effect for seed yield revealed that genotypes react differently to changing environmental conditions (climate and soil properties). Our findings are in agreement with those of Shojaei et al. (2011), Rahnejat and Farshadfar (2015), Miah et al. (2015), Zhang (2017) who determined that canola genotypes react differently to changing environmental conditions.

The result of the GGE biplot analysis showed that the first (PC1) and second principal components (PC2) explained 57.29 and $18.26 \%$ of the total variation in the data matrix of GGE, respectively. Therefore, the first two principal components contributed $75.55 \%$ of the total GGE sum of squares (Figure 1). In a previous similar study, carried out in Iran, with 4 environments and 15 genotypes, Rahnejat and Farshadfar (2015) revealed that the first two principal components explained 65.1 and $19.6 \%$ of the GGE sum of squares (SS). Similarly, Sabaghnia et al. (2011) found that the first two principal components explained $75 \%$ of the seed yield variation for the first year, and $81 \%$ for the second year. The results of those researchers support our findings. Polygon views the GGE biplot showing the mega-environments and their respective highest 
yielding cultivars, and it displays the "which-wonwhere pattern" as a concise summary of the GEI pattern derived from the multi-environment yield trial data set.

Table 4. Means of agronomical traits for 15 rapeseed genotypes tested over eight environments at three locations from 2015 to 2018

\begin{tabular}{lccccccccc}
\hline \multicolumn{1}{c}{ Genotypes } & $\begin{array}{c}\text { DFF } \\
\text { (days) }\end{array}$ & $\begin{array}{c}\text { DLF } \\
\text { (days) }\end{array}$ & $\begin{array}{c}\text { DPM } \\
\text { (days) }\end{array}$ & $\begin{array}{c}\text { PH } \\
(\mathrm{cm})\end{array}$ & CPP & SPC & $\begin{array}{c}\text { TSW } \\
(\mathrm{g})\end{array}$ & $\begin{array}{c}\text { COP } \\
(\%)\end{array}$ & $\begin{array}{c}\text { COY } \\
\left.(\mathrm{kg} \cdot \mathrm{ha})^{-1}\right)\end{array}$ \\
\hline SC-04 (G1) & $164.8 \mathrm{~h}$ & $182.4 \mathrm{fg}$ & $267.0 \mathrm{~h}$ & $140.0 \mathrm{~g}$ & $155.5 \mathrm{~d}$ & $26.1 \mathrm{~b}-\mathrm{d}$ & $4.21 \mathrm{ef}$ & $42.6 \mathrm{f}$ & $1638.4 \mathrm{~d}-\mathrm{f}$ \\
BC-12 (G2) & $166.4 \mathrm{f}$ & $183.2 \mathrm{e}-\mathrm{g}$ & $268.6 \mathrm{~g}$ & $153.6 \mathrm{~cd}$ & $176.9 \mathrm{~b}$ & $26.7 \mathrm{~b}$ & $4.34 \mathrm{~cd}$ & $44.7 \mathrm{~b}$ & $1841.3 \mathrm{bc}$ \\
QS-18 (G3) & $168.4 \mathrm{~d}$ & $184.0 \mathrm{~d}-\mathrm{f}$ & $269.9 \mathrm{e}$ & $152.0 \mathrm{de}$ & $176.5 \mathrm{~b}$ & $25.9 \mathrm{~b}-\mathrm{e}$ & $4.29 \mathrm{de}$ & $44.2 \mathrm{c}$ & $1652.5 \mathrm{de}$ \\
BS-07 (G4) & $164.6 \mathrm{~h}$ & $186.4 \mathrm{bc}$ & $269.3 \mathrm{f}$ & $156.7 \mathrm{bc}$ & $147.4 \mathrm{e}$ & $24.4 \mathrm{~g}$ & $4.28 \mathrm{de}$ & $41.4 \mathrm{~g}$ & $1448.2 \mathrm{~h}$ \\
QB-12 (G5) & $170.9 \mathrm{~b}$ & $187.4 \mathrm{ab}$ & $273.4 \mathrm{c}$ & $157.5 \mathrm{~b}$ & $160.7 \mathrm{~d}$ & $24.7 \mathrm{fg}$ & $4.13 \mathrm{f}$ & $44.6 \mathrm{~b}$ & $1637.0 \mathrm{~d}-\mathrm{f}$ \\
CB-16 (G6) & $163.2 \mathrm{j}$ & $181.4 \mathrm{gh}$ & $265.8 \mathrm{c}$ & $146.2 \mathrm{f}$ & $146.8 \mathrm{e}$ & $26.2 \mathrm{bc}$ & $4.14 \mathrm{f}$ & $43.2 \mathrm{e}$ & $1581.3 \mathrm{fg}$ \\
QC-25 (G7) & $159.3 \mathrm{k}$ & $179.1 \mathrm{l}$ & $264.0 \mathrm{k}$ & $148.6 \mathrm{ef}$ & $168.5 \mathrm{c}$ & $25.8 \mathrm{c}-\mathrm{e}$ & $4.53 \mathrm{ab}$ & $42.3 \mathrm{f}$ & $1691.1 \mathrm{~d}$ \\
SQ-09 (G8) & $164.5 \mathrm{~h}$ & $182.4 \mathrm{fg}$ & $268.6 \mathrm{~g}$ & $156.9 \mathrm{bc}$ & $160.6 \mathrm{~d}$ & $25.4 \mathrm{~d}-\mathrm{f}$ & $4.46 \mathrm{~b}$ & $42.4 \mathrm{f}$ & $1464.4 \mathrm{~h}$ \\
CQ-05 (G9) & $170.7 \mathrm{~b}$ & $187.6 \mathrm{ab}$ & $273.9 \mathrm{~b}$ & $159.2 \mathrm{ab}$ & $156.6 \mathrm{~d}$ & $26.2 \mathrm{~b}-\mathrm{d}$ & $4.20 \mathrm{ef}$ & $41.4 \mathrm{~g}$ & $1539.2 \mathrm{~g}$ \\
SB-28 (G10) & $167.6 \mathrm{e}$ & $184.8 \mathrm{c}-\mathrm{e}$ & $269.4 \mathrm{f}$ & $155.9 \mathrm{~b}-\mathrm{d}$ & $155.4 \mathrm{~d}$ & $26.3 \mathrm{bc}$ & $4.18 \mathrm{ef}$ & $42.6 \mathrm{f}$ & $1777.5 \mathrm{c}$ \\
SÜZER (G11) & $165.4 \mathrm{~g}$ & $184.4 \mathrm{de}$ & $269.6 \mathrm{ef}$ & $158.5 \mathrm{ab}$ & $193.9 \mathrm{a}$ & $25.3 \mathrm{ef}$ & $4.58 \mathrm{a}$ & $43.8 \mathrm{~d}$ & $1588 \mathrm{e}-\mathrm{g}$ \\
ORKAN (G12) & $170.3 \mathrm{c}$ & $187.4 \mathrm{ab}$ & $273.2 \mathrm{c}$ & $149.6 \mathrm{ef}$ & $168.1 \mathrm{c}$ & $25.9 \mathrm{c}-\mathrm{e}$ & $4.43 \mathrm{bc}$ & $43.7 \mathrm{~d}$ & $1772.2 \mathrm{c}$ \\
NK CARAVEL (G13) & $168.7 \mathrm{~d}$ & $185.2 \mathrm{~cd}$ & $272.7 \mathrm{~d}$ & $161.6 \mathrm{a}$ & $192.2 \mathrm{a}$ & $27.6 \mathrm{a}$ & $4.47 \mathrm{~b}$ & $43.2 \mathrm{e}$ & $1855.2 \mathrm{~b}$ \\
EXCALIBUR (G14) & $163.7 \mathrm{l}$ & $180.3 \mathrm{~h} 1$ & $264.5 \mathrm{j}$ & $148.0 \mathrm{f}$ & $195.1 \mathrm{a}$ & $25.6 \mathrm{c}-\mathrm{e}$ & $4.49 \mathrm{ab}$ & $45.5 \mathrm{a}$ & $2073.4 \mathrm{a}$ \\
ELVİS (G15) & $171.8 \mathrm{a}$ & $188.3 \mathrm{a}$ & $274.8 \mathrm{a}$ & $159.7 \mathrm{ab}$ & $168.9 \mathrm{c}$ & $25.1 \mathrm{e}-\mathrm{g}$ & $4.43 \mathrm{bc}$ & $42.6 \mathrm{f}$ & $1772.2 \mathrm{c}$ \\
\hline LSD (0.05) & 0.44 & 1.77 & 0.41 & 3.84 & 5.63 & 0.80 & 0.11 & 0.33 & 69.1 \\
\hline
\end{tabular}

DFF: days to first flowering; DLF: days to last flowering; DPM: days to physiological maturity; PH: plant height; CPP: capsules per plant; SPC: seed per capsule; TSW: thousand seed weight; COP: crude oil percent; COY: crude oil yield. Mean separation by LSD test $(P \leq 0.05)$

Table 5. Average seed yields $\left(\mathrm{kg} \cdot \mathrm{ha} \mathrm{a}^{-1}\right)$ for 15 rapeseed genotypes tested in eight environments

\begin{tabular}{|c|c|c|c|c|c|c|c|c|}
\hline \multirow{2}{*}{ Genotypes } & \multicolumn{7}{|c|}{ Environments } & \multirow{2}{*}{ Mean } \\
\hline & E1 & E2 & E3 & $\mathrm{E} 4$ & E5 & E6 & E7 & \\
\hline SC-04 (G1) & $4357.4 \mathrm{~b}-\mathrm{d}$ & $4241.8 \mathrm{~cd}$ & $3400.1 \mathrm{ef}$ & $4100.7 \mathrm{c}-\mathrm{f}$ & $3563.0 \mathrm{a}-\mathrm{c}$ & $4140.5 \mathrm{~b}-\mathrm{d}$ & $3408.4 \mathrm{~cd}$ & 3862.4 ef \\
\hline BC-12 (G2) & $4653.2 \mathrm{a}-\mathrm{c}$ & $4241.1 \mathrm{~cd}$ & $4130.7 \mathrm{bc}$ & $4016.8 \mathrm{~d}-\mathrm{f}$ & $3643.5 \mathrm{ab}$ & $4467.0 \mathrm{ab}$ & 3859.2 c-f $3997.3 \mathrm{a}$ & $4126.1 \mathrm{~cd}$ \\
\hline QS-18 (G3) & 3605.7 ef & $4137.2 \mathrm{~cd}$ & $4158.4 \mathrm{bc}$ & $3965.1 \mathrm{f}$ & $3414.0 \mathrm{a}-\mathrm{c}$ & 3411.9 ef & $3931.5 \mathrm{c}-\mathrm{f} \quad 3408.2 \mathrm{~cd}$ & $3754.0 \mathrm{f}-\mathrm{h}$ \\
\hline BS-07 (G4) & $3978.2 \mathrm{de}$ & $3806.4 \mathrm{de}$ & $2930.7 \mathrm{f}$ & $3537.1 \mathrm{~g}$ & $2813.8 \mathrm{de}$ & $3779.0 \mathrm{de}$ & 3730.6 ef $\quad 3549.8 \mathrm{bc}$ & $3515.7 \mathrm{i}$ \\
\hline QB-12 (G5) & $3240.8 \mathrm{f}$ & $4127.2 \mathrm{~cd}$ & $3694.9 \mathrm{~b}-\mathrm{e}$ & $4175.4 \mathrm{~b}-\mathrm{d}$ & $3920.5 \mathrm{a}$ & $3143.7 \mathrm{f}$ & 4086.0 c-e $2725.1 \mathrm{f}$ & $3639.2 \mathrm{hi}$ \\
\hline CB-16 (G6) & $3682.1 \mathrm{ef}$ & $4147.3 \mathrm{~cd}$ & 3627.4 c-e & 4217.8 a-d & $3811.9 \mathrm{ab}$ & $3534.5 \mathrm{ef}$ & $3608.2 \mathrm{f}$ & 3666.4 g-i \\
\hline QC-25 (G7) & $4773.0 \mathrm{ab}$ & $4206.2 \mathrm{~cd}$ & $4015.5 \mathrm{~b}-\mathrm{d}$ & $d 4022.3 \mathrm{c}-\mathrm{f}$ & $3363.7 \mathrm{bc}$ & $4534.2 \mathrm{ab}$ & 3701.1 ef $\quad 3452.0 \mathrm{~b}-\mathrm{d}$ & $4008.5 \mathrm{de}$ \\
\hline SQ-09 (G8) & $4145.2 \mathrm{c}-\mathrm{e}$ & $3917.4 \mathrm{de}$ & $4141.7 \mathrm{bc}$ & $4092.0 \mathrm{c}-\mathrm{f}$ & $3417.2 \mathrm{a}-\mathrm{c}$ & $3937.6 \mathrm{c}-\mathrm{e}$ & 3842.4 d-f $3027.3 \mathrm{e}$ & $3815.1 \mathrm{fg}$ \\
\hline CQ-05 (G9) & $3906.5 \mathrm{de}$ & $3650.2 \mathrm{e}$ & $3346.1 \mathrm{ef}$ & $3950.4 \mathrm{f}$ & $3020.0 \mathrm{c}-\mathrm{e}$ & $3790.2 \mathrm{de}$ & $3613.1 \mathrm{f}$ & $3538.0 \mathrm{i}$ \\
\hline SB-28 (G10) & $3783.1 \mathrm{ef}$ & $4043.3 \mathrm{c}-\mathrm{e}$ & $4091.5 \mathrm{~b}-\mathrm{d}$ & $3966.8 \mathrm{ef}$ & $3078.4 \mathrm{c}-\mathrm{e}$ & $3631.7 \mathrm{~d}-\mathrm{f}$ & 3800.2 d-f $2665.8 \mathrm{f}$ & $3632.6 \mathrm{hi}$ \\
\hline SÜZER (G11) & $4892.7 \mathrm{ab}$ & $4738.1 \mathrm{ab}$ & $3750.9 \mathrm{~b}-\mathrm{e}$ & $4325.0 \mathrm{ab}$ & $2616.3 \mathrm{e}$ & $4403.5 \mathrm{a}-\mathrm{c}$ & $4596.7 \mathrm{ab} \quad 3335.2 \mathrm{~cd}$ & $4082.3 \mathrm{~cd}$ \\
\hline ORKAN (G12) & $3343.2 \mathrm{f}$ & $3894.7 \mathrm{de}$ & $3579.1 \mathrm{de}$ & $4225.8 \mathrm{a}-\mathrm{c}$ & $3417.9 \mathrm{a}-\mathrm{c}$ & $3142.6 \mathrm{f}$ & 3855.2 c-f $3687.1 b$ & $3643.2 \mathrm{hi}$ \\
\hline NK CARAVEL (G13) & $4975.6 \mathrm{a}$ & $4428.1 \mathrm{bc}$ & $4186.5 \mathrm{~b}$ & $4171.7 \mathrm{~b}-\mathrm{e}$ & $3817.0 \mathrm{ab}$ & $4726.3 \mathrm{a}$ & $3240.2 \mathrm{de}$ & $4291.0 \mathrm{~b}$ \\
\hline EXCALİBUR (G14) & $5055.3 \mathrm{a}$ & $4922.1 \mathrm{a}$ & 5181.7 a & $4385.2 \mathrm{a}$ & $3864.5 \mathrm{ab}$ & $4807.1 \mathrm{a}$ & $4286.0 \mathrm{bc} \quad 4137.3 \mathrm{a}$ & 4579.9 a \\
\hline ELVİS (G15) & $4343.1 \mathrm{~b}-\mathrm{d}$ & $4050.4 \mathrm{c}-\mathrm{e}$ & $5304.2 \mathrm{a}$ & $4110.5 \mathrm{c}-\mathrm{f}$ & $3350.9 \mathrm{~b}-\mathrm{d}$ & $4081.4 \mathrm{~b}-\mathrm{d}$ & $4212.4 \mathrm{~b}-\mathrm{d} 4107.1 \mathrm{a}$ & $4195.0 \mathrm{bc}$ \\
\hline Mean & $4182.3 \mathrm{~A}$ & $4170.1 \mathrm{~A}$ & $3969.3 \mathrm{~A}$ & $4084.2 \mathrm{~A}$ & $3407.5 \mathrm{~B}$ & $3968.7 \mathrm{~A}$ & $3973.8 \mathrm{~A} \quad 3364.7 \mathrm{~B}$ & \\
\hline
\end{tabular}




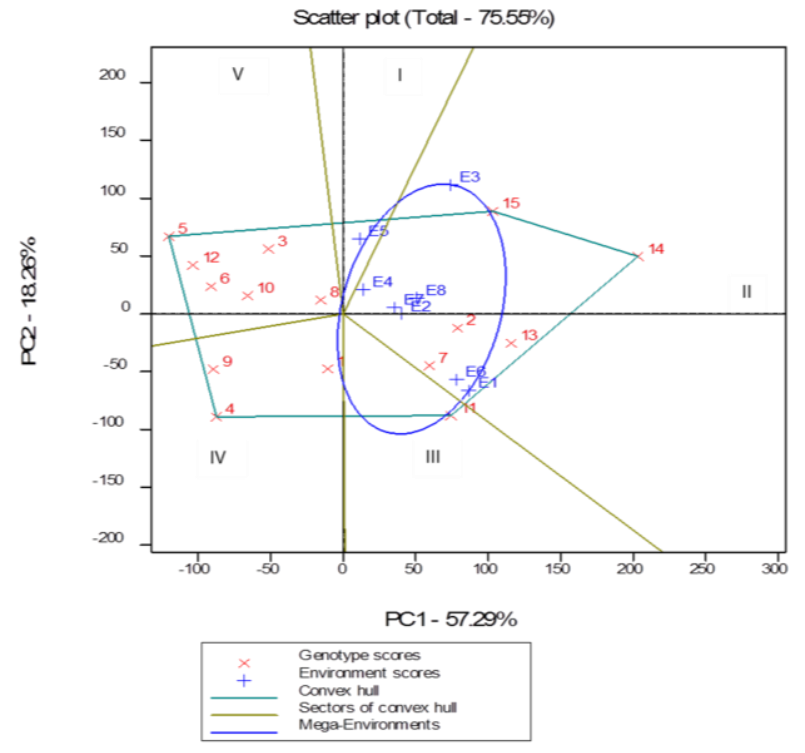

Figure 1. Polygon view of genotype $x$ environment interaction for canola genotypes over eight environments

In the present study, five lines in Figure 1 divided the biplot into five sectors or five megaenvironments (I to V), and the environments fall only into two of them (I and II). The vertex genotypes in this study were genotypes $14,15,11$, 5, and 4. One environment (E5) fell into the first mega-environment (I). Genotype 5 was the vertex genotype for this mega-environment. The other seven environments (E1, E2, E3, E4, E6, E7, and E8) fell into the second mega-environment (II). Three vertex genotypes (14 and 15) were identified for this mega environment. Genotype 14 was high yielding in the environments E2, E4, E7, and E8, while genotype 15 was the winning genotype in E3, and genotype 11 also in E1 and E6. In addition, genotypes 13 and 14 also performed high yield in those two environments (Table 5; Figure 1). The vertex genotypes for these mega-environments were classified as winning genotypes for the same megaenvironments. It was determined that other genotypes falling into sectors where there were no environments showed poor adaptation to all environmental conditions. Thus, according to the GGE biplot graphic, genotype 4, which was the vertex genotype of the fourth mega environment, was the lowest yielding genotype and showed relatively poor adaptation to environmental conditions. In contrast, genotype 5, which was the vertex genotype of the fifth mega environment, was the highest yielding in this environment, but this genotype showed poor adaptation to other environmental conditions (Table 5; Figure 1). GGE biplot produces the best polygons to view or visualize the genotype $\mathrm{x}$ environment interaction pattern (Yan and Kang, 2003). Visualization of the 'Which-won-where' pattern in the polygon view is helpful to estimate the possible existence of different mega-environments in the target environment (Yan and Rajcan, 2002; Yan and Tinker, 2006). Yan et al. (2000) suggested that GGE biplot is an essential tool for addressing the mega-environment issues, by showing which cultivar won in which environments, and thus it is an effective visual tool in mega-environment identification. Yan and Tinker (2006) reported that the vertex genotypes were the most responsive ones, as they have the longest distance from the origin in their direction. In their work, Rahnejat and Farshadfar (2015) found two megaenvironments and stated that the first one contained four environments and one genotype in one environment, and another genotype in the other three environments gave the highest performances. The same researchers found that three different genotypes exhibited the highest average yield and stability, while the other three showed the lowest. The results obtained in previous studies were consistent with our findings where winning genotypes for different environmental conditions were determined.

Yang et al. (2009) emphasize that the greater the genotype projection in the AEC ordinate axis, the greater the genotype instability, representing a greater interaction with the environments. In the present study, according to the GGE biplot graph, six genotypes $(14,15,13,2,11$, and 7$)$ i.e. the genotypes at the positive side of the abscissa showed higher performance than the general yield average. On the other hand, genotypic stability is quite crucial, in addition to genotype yield mean.

A longer projection to the AEC ordinate, regardless of the direction, represents a greater tendency of the GEI of a genotype, which means it is more variable and less stable across environments or vice versa (Rahnaejat and Farshadfar, 2015). Accordingly, although genotypes 14 and 15 were the highest yielding, these genotypes, that have a longer projection to the AEC ordinate, were less stable genotypes and thus adapted to specific environmental conditions. 
Besides, genotype 2 was considered to be a high yielding and stable genotype. As seen from Table 5 and Figure 2, other genotypes (G1, G3, G4, G5, G6, G8, G9, G10, and G12) were judged to be low-yielding and some of them unstable. Shojaei et al. (2011) reported that the cultivars G1, G3, G7, and G8 were identified as more stable than the rest of the cultivars, and the cultivar G1 was declared as the best cultivar. Rahnejat and Farshadfar (2015) detected that three genotypes (G7, G9, and G14) exhibited the highest mean yield and stability, while three other genotypes (G1, G8 and G5) displayed the poorest mean yield and stability.

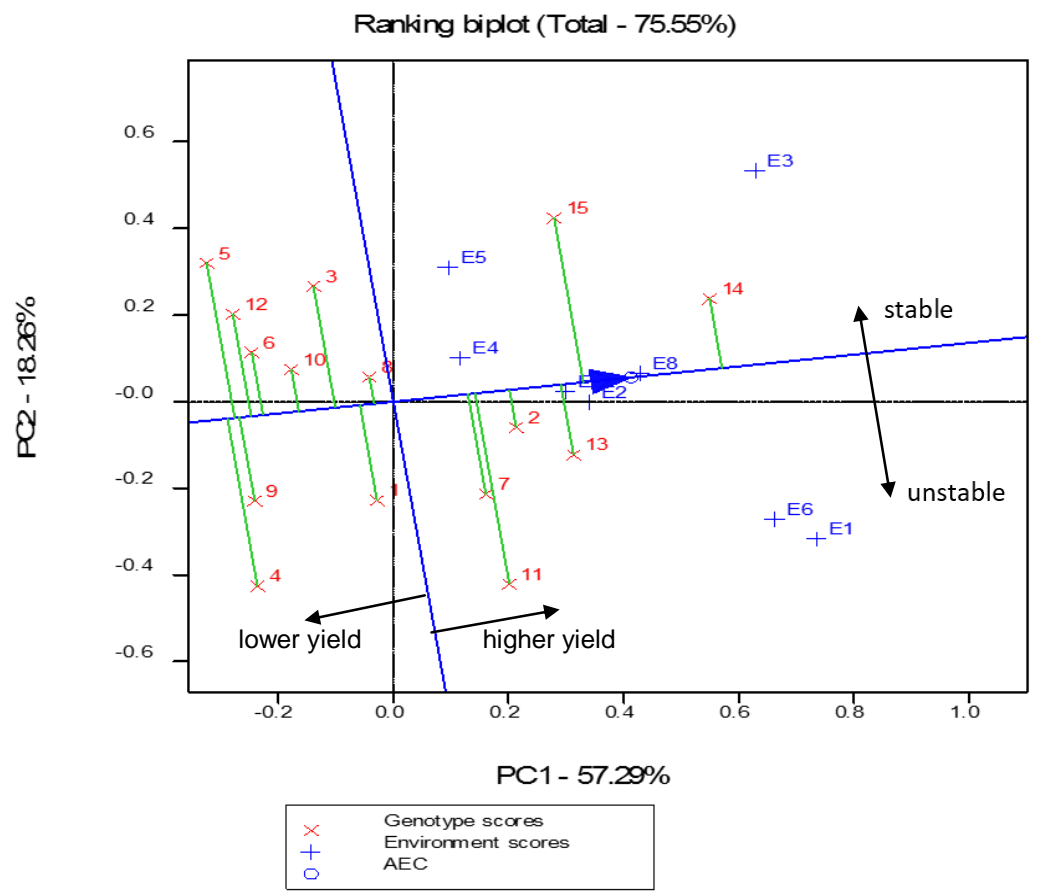

Figure 2. Average environment coordination (AEC) views of the GGE biplot for the means performance and stability of genotypes

The GGE biplot, which displays the average yield performance and stability of the genotypes with the ideal genotype, is presented in Figure 3. An ideal genotype should have the highest mean performance and be stable (i.e. perform the best in all environments). An ideal genotype is located in the first concentric circle of the GGE biplot graphic and the genotypes that are close to the ideal genotype are defined as the desired genotypes.

The ideal genotype or environment concept of GGE biplot indicates that the closer a genotype or environment is located relative to the "ideal" genotype or environment; the more desirable it is in terms of both mean performance and stability. Figure 3 revealed that G14 which fell into the center of concentric circles, were the ideal genotype in terms of higher yield ability and stability, compared with the rest of the genotypes. Also, G15 and G13, which were close to G14, were the more desirable genotypes than other genotypes. For all that, genotypes G4, G5, G9, and G12 were the poorest performer (lowest yielder) for that matter. Shojaei et al. (2011) suggested that they identified four ideal canola genotypes that have both high yield and high stability performances across the test environments. Similar results were obtained by Marjanović al. (2008), Miah et al. (2015), Rahnejat and Farshadfar (2015), and Nowosad et al. (2016), who also observed the presence of ideal canola genotypes having the high yield and high stability performances across different environments.

In the present study, E8 and E6 were the closest environments to the ideal environment (Figure 4). Thus, E8 and E6 were considered the desired environments. Also, E1 and E3 located close to environments E8 and E6 could also be considered ideal environments. Those close to the 
ideal environment were most discriminating of the genotypes and represent the best of all environments, whereas the other environments gave very little information about genotypic differences. The suitability of E8 and E6 were high in representing all genotypes. The concentric circles nearest sites were high for their stability in representing the genotypes. In contrast, E4 and E5 were the worst environments for the 15 genotypes studied

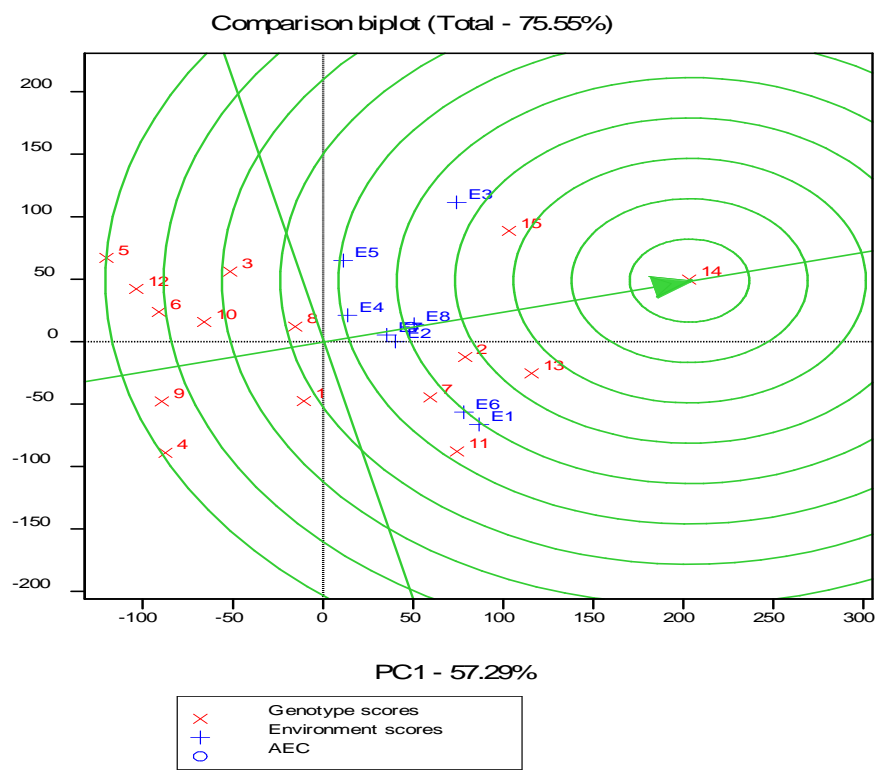

Figure 3. GGE biplot view of the performance of the other genotypes relative to the ideal genotype

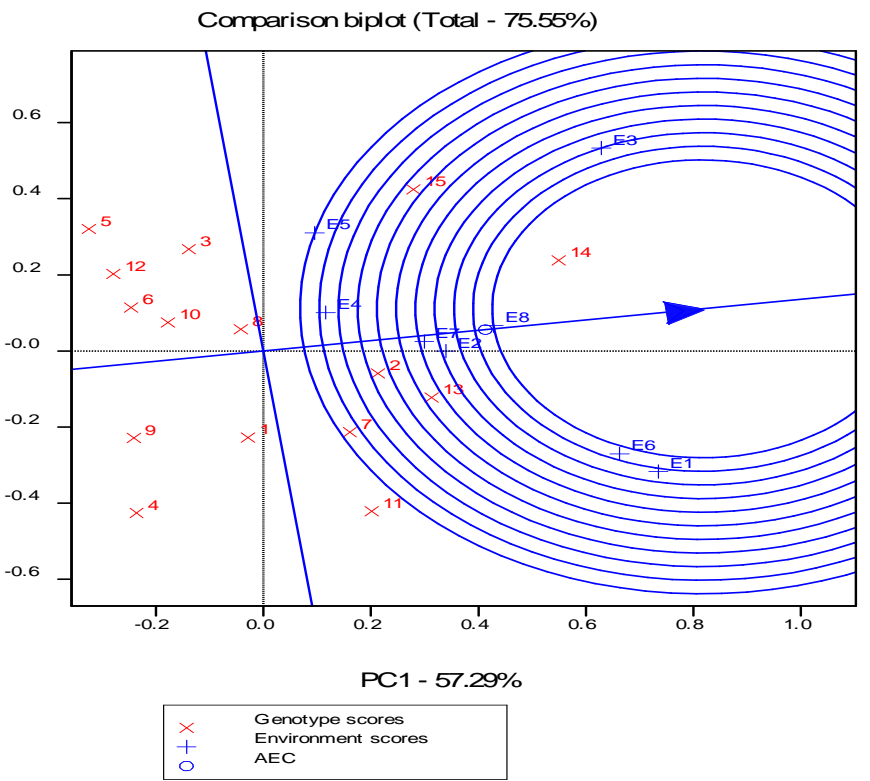

Figure 4. GGE biplot view of the performance of the other environments relative to the ideal environment

The AEC concentric circle GGE biplot method is best to estimate the discriminating vs. representing ability for assessing the genotypes (Yan and Tinker, 2006; Yan et al., 2007; Atnaf et al., 2013). In a similar study conducted in Iran, Shojaei et al. (2011) reported that location Karaj was recognized as the best region of the classification and ranking of genotypes. In the research of Rahnejat and Farshadfar (2015), it was found that one environment was the best representative of the overall environments and the most powerful to discriminate genotypes 
performance.

Environment E8 was the ideal in environmental ranking and had high stability. It fell into the center of concentric circles and was the best representative in all environments, and the most suitable to discriminate genotypes performance. In contrast, E1 and E3 exhibited poor stability (Figure 5). These environments were unfavourable with their low stability in representing genotypes. However, E1 and E3 environments could be considered as special environmental conditions. Miah et al. (2015) reported that both first and second environments had the longer vectors, thus they were the best for genetic discrimination of genotypes whereas the third environment was the least representative one.

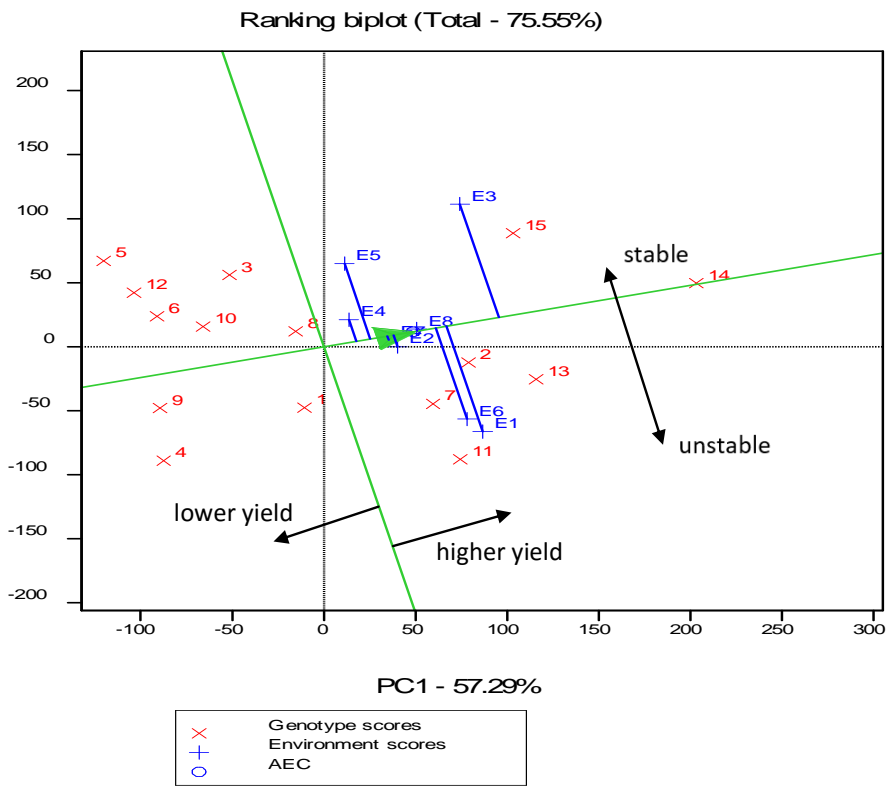

Figure 5. Average environment coordination (AEC) views of the GGE biplot for the means performance and stability of environments

\section{CONCLUSIONS}

Seed yield of canola genotypes in the present study is strongly influenced by the GEI of the total variation. The result of the GGE biplot analysis showed that the first principal components (PC1) and the second principal components (PC2) explained $57.3 \%$ and $18.2 \%$ of the total variation in the data matrix of GGE, respectively. Therefore, the first two principal components contributed $75.5 \%$ of the total GGE sum of squares.

According to GGE biplot analysis, G14 were the ideal genotype in terms of higher yield ability and stability, compared with the rest of the genotypes. Also, G15 and G13, which were close to G14, were the more desirable genotypes than other genotypes. For all that, genotypes G4, G5, G9, and G12 were the poorest performer (lowest yielder) for that matter. E8 and E6 were the closest to the ideal environments. Thus, the E8 and E6 were considered the desired environments.
Essentially, these environments were the best representative of all environments and the most suitable to discriminate genotypes performance, whereas the other environments gave very little information about genotypic differences.

The GGE biplot model effectively interpreted the G, E, and GEI variation present in this study and best revealed the relationships between both genotypes and environments. At the same time, this method described mega-environments, ideal genotypes, and environments. GGE biplot analysis showed that the polygon view of a biplot was an excellent way to visualize the interactions between genotypes and environments.

\section{ACKNOWLEDGEMENTS}

The authors are grateful to The Scientific and Technological Research Council of Turkey (TUBITAK) for financial support as the result reported in this study are part of the "Project No: 
1150367 " scheme (fully financed by the TUBİTAK).

\section{LITERATURE CITED}

1. Atnaf, M., S. Kidane, S. Abadi, and Z. Fisha. 2013. GGE biplots to analyze soybean multienvironment yield trial data in north Western Ethiopia. J. Plant Breed. Crop Sci. 5 (12): 245254.

2. Marjanović-Jeromela, A., R. Marinković, J. Atlagić, D. Saftić-Panković, D. Miladinović, P. Mitrović, and V. Miklič. 2008. Achievements in canola (Brassica napus L.) breeding at Institute of field and vegetable crops (In Serbian). Zbornik Radova Instituta za Ratarstvo i Povrtarstvo, Novi Sad 45(1): 131143.

3. Miah, A., R. Golam, A.K. Mian, and M. Rohman 2015. Evaluation of canola lines for seed yield stability. International Journal of Agronomy and Agricultural Research 7(6): 12-19.

4. Moghaddam, M.J., and S.S. Pourdad. 2011. Genotype $\mathrm{x}$ environment interactions and simultaneous selection for high oil yield and stability in rainfed warm areas canola (Brassica napus L.) from Iran. Euphytica 180: 321-335.

5. Nowosad, K., A. Liersch, W. Popławska, and J. Bocianowski. 2016. Genotype by environment interaction for seed yield in canola (Brassica napus L.) using additive main effects and multiplicative interaction model. Euphytica 208: 187-194.

6. Otoo, E. and R. Asiedu. 2006. Cultivar evaluation and mega-environment investigation of Dioscorea cayenensis cultivars in Ghana based on the GGE biplot analysis. Journal of Food, Agriculture and Environment 4(3-4): 162-166.

7. Rahnejat, S.S. and E. Farshadfar. 2015. Evaluation of Phenotypic Stability in Canola (Brassica napus L.) Using GGE-biplot. Int. J. Biosci. 6(1): 350-356.

8. Sabaghnia, N., H. Dehghani, B. Alizadeh, and M. Moghaddam. 2011. Yield analysis of canola (Brassica napus L.) under water-stress conditions using GGE biplot methodology. Journal of Crop Improvement 25: 26-45.

9. Shojaei, S.H., K. Mostafavi, M. Khodarahmi and M. Zabet. 2011. Response study of canola (Brassica napus L.) cultivars to multienvironments using genotype plus genotypeenvironment interaction (GGE) biplot method in Iran. African Journal of Biotechnology 10(53): 10877-10881.

10.Yan W. 2001. GGE biplot: A Windows application for graphical analysis of multienvironment trial data and other types of twoway data. Agron J. 93: 1111-1118.

11.Yan W. 2002. Singular-value partitioning in biplot analysis of multi-environment trial data. Agron. J. 94: 990-996.

12.Yan, W., L.A. Hunt, Q.L. Sheng, and Z. Szlavnics. 2000. Cultivar evaluation and megaenvironment investigation based on the GGE biplot. Crop Sci. 40: 597-605.

13.Yan, W. and L.A. Hunt. 2002. Biplot analysis of multi-environment trial data, In M. S. Kang, ed. Quantitative Genetics, Genomics and Plant Breeding. CAB International, Wallingford.

15.Yan, W. and M.S. Kang. 2003. GGE Biplot Analysis: A Graphical Tool for Breeders, Geneticists and Agronomists. 1st Edn., CRC Press, Boca Raton, FL., USA., Pages: 288.

14.Yan, W. and I. Rajcan. 2002. Biplot analysis of test sites and trait relations of soybean in Ontario. Crop Sci. 42: 11-20.

15. Yan, W. and N.A. Tinker. 2005. An integrated biplot analysis system for displaying, interpreting, and exploring genotype $\times$ environment interaction. Crop Science 45: 1004-1016.

16.Yan, W. and N.A. Tinker. 2006. Biplot analysis of multi-environment trial data: Principles and applications. Can. J. Plant Sci. 86: 623-645

17.Yan, W., M.S. Kang, B. Ma, S. Woods, and P.L. Cornelius. 2007. GGE biplot vs. AMMI analysis of genotype-by-environment data. Crop Sci. 47: 643-655.

18. Yang, R.C., J. Crossa, P.L. Cornelius, and J. Burgueño. 2009. Biplot analysis of genotype $\times$ environment interaction: Proceed with caution. Crop Sci. 49: 1564-1576.

19.Zhang, H., J.D. Berger, and C. Herrmann. 2017. Yield stability and adaptability of canola (Brassica napus L.) in multiple environment trials. Euphytica 213: Article 15. 